history, and helping unions to write their own history. Several sessions took up "where we have come from/where we are going" questions and asked "Where have we gone since Shorter and Tilly?" or explored the "problems of comparative labor history."

There was much discussion throughout of the usefulness of paradigms from older styles of labor history. Did tradition inhibit broadening the discussion to new groups of workers-especially women and racial- or ethnic-minority workers, in the paid economy or in the home? There was a clear sense that those methods and frameworks that have served to limit labor history should be examined and redefined.

Finally, the SSHA meeting also included exciting research in women's history, family history, the study of migration and immigration, the impact of the state and of welfare policies on populations, and economic history. Overall, the conference was very much a working intellectual group, with almost everyone presenting as well as serving as audience. The 1991 conference will be in New Orleans.

\title{
American Studies Association: Internationalism and the U.S. Working Class
}

\section{Donna Gabaccia}

Mercy College

An audience of about twenty joined panel members Joe Trotter, Bruce Levine, Noel Ignatieff, and Donna Gabaccia for a round table discussion of working-class internationalism at the American Studies Association's November 1990 conference "Rivers of Contrast" in New Orleans. The round table was organized by Marcus Rediker and chaired by Peter Linebaugh. Each panel member presented some thoughts about the meaning, significance, and practice of internationalism for a particular group of American workers-African-Americans, Irish, Germans, and Italians.

Noel Ignatieff reported on the cooperation of Irish and black inmates in a Philadelphia prison, arguing that the prison was a workplace characterized by cross-racial class solidarity of a kind not normally seen among Irish and AfricanAmerican workers. Bruce Levine explored both the home-country origins of German immigrants' special activism in the U.S. labor movement and their strong support for the abolition of slavery - something that differentiated them sharply from their Irish counterparts. Joe Trotter and Donna Gabaccia emphasized the striking identity of racial or ethnic concerns with internationalism for AfricanAmerican and Italian workers respectively. African-Americans were concerned with the anti-colonial struggles of blacks in Africa and elsewhere. The far-flung global migrations of 14 million Italian laborers and political exiles guaranteed circulation of ideas, experience, and ideologies between Italy and "Little Italies" around the globe. 
A lively discussion raised more questions than could be answered. Parallels were drawn between prisoners and seamen as cases where workers of many backgrounds were brought into enforced contact. Many from both audience and panel noted that the least-skilled workers - first the Irish, later the Italians - were not viewed as "white men"; the conditions under which such workers became "white" and the effect of this transformation on their relations with native-born African-Americans need further study. Conflicting explanations for the very different reactions of German and Irish immigrants to slavery and emancipation were argued. Whether or not missionary activity by Catholic or African-American churches should be considered or compared to working-class internationalism was also discussed.

\title{
North American Labor History Conference: Ethnicity and Class
}

\author{
William G. Falkowski \\ Erie Community College, Buffalo
}

"Ethnicity and Class in Canada and the United States" was the topic of a 1990 North American Labor History Conference panel chaired by Larry Kulisek (University of Windsor). A paper by David Bright (University of Calgary), entitled " 'We are All Kin': Class, Ethnicity and Labor in Calgary, 1919," challenged what Bright termed the "romanticized myth" of widespread radicalism among Canadian workers during the World War I period. Bright proceeded to pick away at what "orthodox" scholars have offered as contextual evidence of workers' growing class consciousness. In response to claims that a boom period of Canadian economic prosperity ended with the advent of war, Bright showed that real wages of workers in Calgary remained generally stable. Although other scholars have held that conscription led to intensified class consciousness, Bright argued that the large number of Calgary workers who enlisted in the armed forces indicates otherwise. As further evidence of workers' less-than-radical inclinations, Bright pointed to the meager extent of unionization in Calgary, union locals' lack of enthusiastic support for Canada's One Big Union movement, and their reluctance to stage sympathy strikes for Winnepeg workers.

Bright explained that working-class radicalism in Calgary, in marked contrast to the situation in Winnepeg, was attenuated by cordial working class-middle class relations that revolved around a mutual belief in the efficacy of the existing order. This, Bright suggested, was the result of the homogeneity of Calgary's ethnic population, which was 75 to 80 percent British, compared to the more heterogenous population of Winnepeg, which included greater numbers of workers from Eastern Europe. In conclusion, Bright argued that "kinship not conflict" characterized social relations in Calgary. 